\title{
Roland Barthes por Roland Barthes: entre la autobiografía y la autoficción*
}

\author{
Angélica TORNERO \\ Universidad Autónoma del Estado de Morelos
}

\begin{abstract}
El interés por examinar la autobiografía y caracterizarla como género literario aumentó en el siglo XX. En la primera mitad, se publicaron obras fundacionales, como las de Georg Misch y Georges Gusdorf. Hacia los años setenta, Georges May, Philippe Lejeune y James Olney, entre otros, avanzaron en la tipificación del género. Paradójicamente, en ese mismo siglo, algunos autores exploraron formas de escritura autobiográfica, alejándose precisamente de las propiedades normalizadas, como la expresión "sincera", la construcción de una identidad de manera esencialista y el desarrollo del estilo individual. Ejemplo de ello es L'Âge d'homme de Michel Leiris, que data de 1939. Más tarde, en 1975, apareció Roland Barthes por Roland Barthes, libro que resulta difícil clasificar, ya que no cumple con las características del género autobiográfico, y tampoco se trata de un diario o un ensayo. En 1977, Serge Doubrovsky utilizó el término autoficción para referirse a su propia novela Fils y cuestionar el estatuto de la autobiografía. A partir de entonces, se ha reflexionado teóricamente sobre esta noción, intentando fijar características de un posible nuevo género. El objetivo de este artículo es reflexionar sobre los aspectos que provocan ambigüedad en Roland Barthes por Roland Barthes, problematizando su clasificación, sea como autobiografía, sea como autoficción.
\end{abstract}

PALABRAS CLAVE: autobiografía, autoficción, escrituras del yo.

Interest in examining the autobiography and characterize it as a literary genre has increased in the 20th century. In the first half, Georg Misch and Georges Gusdorf published their foundational works. Towards the 1970s, Georges May, Philippe Lejeune, James Olney, among others, advanced in the classification of the genre. Paradoxically, at the beginning of this century, some authors explored forms of autobiographical writing, just away from the standardized properties, as the "honest" expression, the construction of an identity an essentialist way and the development of individual style. An example of this is Michel Leiris' L'Âge d'homme, published in 1939. Later, in 1975, Roland Barthes brought out Roland Barthes

\footnotetext{
* En este artículo se presenta parte de los avances de la investigación que se llevó a cabo en 2015 (durante el año sabático), en el marco del proyecto titulado "Horizontes teóricos y críticos en torno a la figura autoral contemporánea" (PAPIIT IN405014-3), de la Facultad de Filosofía y Letras de la Universidad Nacional Autónoma de México.
} 
by Roland Barthes, a book that is difficult to classify, as it is neither an autobiographical text, nor a diary. In 1977, Serge Doubrovsky used the term autofiction to refer to his own novel, Fils, and to question the autobiographical genre statute. From then on, some scholars have pondered theoretically this notion, trying to fix characteristics of a possible new gender. The aim of this work is to reflect on aspects that turn Roland Barthes by Roland Barthes into an ambiguous book, hard to categorize, even as autobiography, or as autofiction.

KEY WORDS: autobiography, autofiction, self-writing.

\section{Introducción}

Los movimientos artísticos y literarios de mediados del siglo XIX no solamente impugnaban la simbólica social que afirmaba los valores de la burguesía, sino que también rechazaban el abordaje academicista, la aproximación reflexiva, teorizante, que se había apoderado de los críticos. En 1855, Charles Baudelaire publicó Pequeños poemas en prosa no para sorprender con sus innovaciones, sino para refutar la teoría de los géneros y, unos años después, publicó Las flores del mal, entre otros propósitos, para cuestionar un modo de comprender el arte y la literatura, basado en categorías abstractas. En El pintor de la vida moderna, el poeta también expuso esta inquietud a partir de sus reflexiones sobre la plástica. Aquí, Baudelaire señala que todo pintor antiguo tuvo su modernidad, la cual se expresa, por ejemplo, en el traje singular que porta el retrato o en el peinado de la época. Estas singularidades no pueden ser menospreciadas y no se puede prescindir de su "elemento transitorio, fugaz" (2014: 22), porque se corre el riesgo de caer en el "vacío de una belleza abstracta e indefinible" (22). El arte de otras épocas no puede ser pensado a partir de abstracciones, porque aquellos aspectos de innovación quedarían supeditados a categorías fijas. Lo moderno, el elemento nuevo, en cada época, se caracteriza por ser transitorio y fugaz, y tiene que ser comprendido así. En concordancia con Baudelaire, hacia finales del siglo decimonónico y las primeras décadas del XX, muchos escritores y artistas se darán a la tarea de desenmascarar el juego racional de las precisiones categoriales con el que se había pretendido comprender el arte.

No solamente los artistas rebatían las aproximaciones teorizantes que avasallaban a las expresiones artísticas, algunos pensadores también se dieron a la tarea de cuestionar la metafísica con la que, pretendidamente, se estructuraban teorías coherentes de la realidad. Nietzsche pondría en tela de juicio las certezas y verdades provenientes de la ciencia, arguyendo que lo que llamamos mundo es un conjunto de fantasías y errores metafísicos, ilusiones que crean los discursos unificadores promovidos por la razón. Las contradicciones de un mundo burgués y capitalista resquebrajaban los discursos generalizadores, que no sostenían más el sueño de la unificación por vía del pensamiento racional y, por lo tanto, de la ciencia. El proyecto de emancipación 
humana, caro a la Ilustración, se quebrara y, por la grietas, emanaba un proceso de creciente cientifización y burocratización de la vida.

Si la metafísica resultaba ilusoria, si la filosofía no bastaba ya para explicar un mundo hundido en contradicciones insalvables, si, incluso, aproximaciones filosóficas, críticas, como las de Horkheimer y Adorno, eran insuficientes, sobre todo para este último, algunas expresiones artísticas y literarias, con sus estrategias desestabilizadoras de certezas, parecían ofrecer una alternativa no ya para construir nuevas representaciones del mundo, a manera de ilusiones, sino para desconstruir las existentes. Ante la insuficiencia del lenguaje filosófico para alcanzar las notas más altas de las contradicciones que asolaban al mundo, Adorno se inclinó por el arte, que mostraba, que presentaba a ese mundo, porque su propio carácter era aporético. Las auténticas obras de arte, escribió el filósofo, son aquellas que acentúan al máximo la contradicción entre lo hecho y la apariencia; son aquellas que carecen de intención, que muestran al mundo desprovisto de sentido (Adorno, 2006).

No es fácil trazar en unas cuantas líneas el complejo panorama del arte del siglo XX. Baste decir que, de una manera u otra, las expresiones de vanguardia y posvanguardia, así como algunas de las llamadas posmodernas, han refutado teorías de géneros, resquebrajado conceptos, como los de personaje, narrador, incluso la idea misma de literatura y de otras artes. Esta impronta, ya observada por Adorno, prevalecerá, insistimos, con distintas configuraciones, situaciones y contextos. Es decir, a partir de la segunda mitad del siglo XIX, el arte fractura los metarrelatos institucionalizados. Adorno consideraba que el arte de posvanguardia había perdido aquella fuerza emancipatoria, por haber sido sometido a la lógica de la industria cultural. Sin negar tal afirmación, agregamos que, aun cuando esto haya sido así, después de la Segunda guerra, con el desarrollo de la tecnología de comunicaciones, el mundo se ha vuelto mucho más complejo y, con ello, los procesos de creación, producción y circulación del arte, por lo que no es fácil dilucidar qué expresiones son o no críticas. Nos parece que un estudio profundo de las situaciones y contextos es imprescindible para lograr mayor claridad al respecto.

Además de artistas y escritores, desde hace décadas, críticos y estudiosos de diversas latitudes, como Michael Foucault, Jacques Derrida y Julia Kristeva, se han dado a la labor de cuestionar las certezas conceptuales, los discursos con los que se constituyó la "institución" artística y literaria. Tras su periodo estructuralista, Roland Barthes no sólo se sumó a esta tarea, sino que también se convirtió en uno de los pensadores más destacados de la corriente posestructuralista, que ha deconstruido discursos con los que se constituyó el Estado moderno. En Crítica y verdad, ensayo publicado en 1966, Barthes cuestiona la manera en que se realiza la crítica literaria, hundida en el cientificismo y la institucionalidad, y propone una crítica que consista en la escritura de un segundo texto, a partir del primero, el propiamente literario (1971: 48). Más tarde, en el ensayo "La muerte del autor", que data de 1968, afirma que en cuanto el hecho pasa a ser relatado, "sin más función que el propio ejercicio del símbolo, se produce esa ruptura, la voz pierde su origen, el autor entra en su propia muerte" (1981: 
65-66). Por falta de espacio, no nos referiremos aquí a los numerosos textos en los que Barthes desconstruye conceptos de la literatura e, incluso, la idea misma de literatura. Nos concentraremos en el texto que da lugar a la reflexión que nos interesa realizar en este artículo: Roland Barthes por Roland Barthes. Este libro, publicado en 1975, no puede ser fácilmente clasificado, debido a que rompe los límites genéricos. No se trata de una autobiografía y tampoco de una memoria ni de un diario o ensayo. Incluso, al retomar la noción de autoficción — con la que el escritor francés Serge Doubrovsky caracterizó a su novela Fils (1977) para diferenciarla de la autobiografía - con la intención de asir este libro barthesiano, el término se desdibuja, lo que nos permite confirmar que el crítico francés llevó las distinciones conocidas y las innovadoras al límite.

Una lectura rápida del título, Roland Barthes por Roland Barthes, puede llevarnos a considerar que el autor escribió sobre sí mismo: el nombre del libro es Roland Barthes y el autor es Roland Barthes. Sin embargo, una revisión atenta puede revelarnos otros aspectos de este juego del lenguaje. Barthes tuvo buen cuidado de elegir un título que, además de indicar que escribiría sobre sí mismo, expresara la propuesta general de este libro y, dicho sea de paso, de gran parte de su trayectoria intelectual: diseminar el sentido. En este título hay un sofisticado juego que provoca un indecidible, en términos de Derrida. Si consideramos que la preposición por [par, en francés] es utilizada para construir un enunciado en voz pasiva, del que se ha omitido el verbo, podríamos deducir que el libro titulado Roland Barthes ha sido escrito por Roland Barthes. Sin embargo, existe otra posibilidad: que la preposición por [par] funcione como gozne, como bisagra o articulación de un Roland Barthes con otro Roland Barthes, lo cual estaría mucho más cercano a la propuesta contenida en dicho libro, como veremos más adelante. Así, nos enfrentamos a un sintagma que funciona como título y nombre de autor, a la vez.

Esta cuestión observada en el nombramiento del libro se hace extensiva a toda la propuesta en él contenida, que reiteradamente plantea interrogantes en torno a su posible tipificación genérica, a su temática, a su estructura y, evidentemente, a aspectos como la voz, la perspectiva, el espacio-tiempo y la identidad. En este artículo reflexionaremos, especialmente, sobre los aspectos que provocan que este libro sea ambiguo desde el punto de vista genérico.

\section{De la autobiografía a la autoficción}

Para abordar el asunto de la autobiografía, tomaremos a uno de los estudiosos más destacados en el siglo XX, el investigador francés Philippe Lejeune. El pensamiento de este autor es importante no sólo por su contribución a la indagación sobre este fenómeno, sino también porque ha mostrado, con constantes ajustes y reconsideraciones en torno a sus reflexiones, la dificultad de caracterizar genéricamente a la autobiografía, sobre todo en el siglo XX. En sus distintas aproximaciones, este crítico ha realizado cambios que, como han señalado Paul John Eakin (1994: 17-18) y el propio Lejeune 
(1994: 131-132), en ocasiones, resultan contradictorios. Algunos cuestionamientos que modificaron la perspectiva de Lejeune fueron provocados precisamente por la obra que aquí abordamos, Roland Barthes por Roland Barthes.

En L'autobiographie en France, publicada en 1971, Philippe Lejeune señala que la autobiografía es un fenómeno occidental, cuyo origen puede establecerse en 1782, con la publicación de los seis primeros libros de las Confesiones de Rousseau. De acuerdo con el autor, en la segunda mitad del siglo XVIII surgió en Francia - y en Europa, en general - un nuevo tipo de escritura que cambió profundamente la naturaleza de la comunicación literaria (Lejeune, 1971: 38). Aun cuando es posible advertir la presencia de escrituras del yo desde la Antigüedad grecorromana, Lejeune afirma que es en ese siglo cuando se constatan: la existencia de una historia verdadera de la personalidad, el sentimiento de originalidad y la distinción entre biografía y autobiografía como nociones modernas (1994: 44). En este primer estudio, Lejeune define la autobiografía como: "Relato retrospectivo en prosa que alguien hace de su propia existencia, cuando pone el acento principal en su vida individual, en particular, en la historia de su personalidad" (1994: 10).

Tras realizar ciertas consideraciones sobre esta definición, dos años después, en 1973, el crítico francés publicó una de sus obras más reconocidas sobre la autobiografía, titulada El pacto autobiográfico, en la que matizó la definición y agregó aspectos fundamentales para la comprensión del fenómeno, sobre todo a partir de la pragmática. Las modificaciones a la definición anterior son mínimas: "Relato retrospectivo en prosa que una persona real hace de su propia existencia, poniendo énfasis en su vida individual y, en particular, en la historia de su personalidad" (1994: 50). En relación con la pragmática, Lejeune escribió: "He concebido mi definición no [...] examinando [...] los textos, sino poniéndome en el lugar de un lector de hoy que trata de distinguir algún orden en la masa de textos publicados cuyo rasgo en común es que cuentan la vida de alguien" (1994: 50). Lejeune propone partir del texto, no para ir al autor ni para establecer los cánones de un género literario, sino para captar el funcionamiento de los textos a partir del lector, que, aclara, es él mismo. Además, impone una limitación a su propia definición, al explicar que ésta abarca dos siglos, desde 1770, y que solamente incluye a la literatura europea (1994: 50). Con estas consideraciones, Lejeune concluye que para que haya autobiografía es necesario que coincida la identidad del autor con la del narrador y la del personaje y que el autor haga explícito que se trata de hechos de la vida. En Yo es otro, texto publicado en 1980, el autor amplió la reflexión sobre la identidad, al incorporar los casos de autobiografía en tercera persona y autor múltiple, que había dejado de lado en 1973.

Dos años después, Lejeune publicó El pacto autobiográfico (bis) (1982), libro en el que cuestiona gran parte de las nociones que sustentan sus propuestas anteriores. La reflexión crítica sobre sus propias consideraciones lo condujo a realizar un cuestionamiento profundo no solamente de la definición, del vocabulario empleado, de la noción de contrato o pacto, sino también y, de manera importante, de la idea de identidad. Es en este último aspecto en el que nos centraremos. 
En El pacto autobiográfico, Lejeune diseñó una matriz para explicar la correlación entre el tipo de pacto y el uso de los nombres propios (autor, narrador, personaje). En esta matriz, el autor deja dos casillas en blanco, una de las cuales muy pronto será llenada por el escritor y profesor universitario Serge Doubrovsky. Al dejar en blanco esta casilla, en la que se cruza el tipo de pacto novelesco con el nombre de autor, Lejeune excluye, a priori, la posibilidad de que cuando los lectores se dispongan a leer una novela esperen que haya identidad nominal entre el autor, el narrador y el personaje. Cuando Doubrovsky abre camino a esta posibilidad, no sólo con su propia novela, Fils, sino con el neologismo "autoficción", que ubica en la casilla en blanco, plantea una manera diferente de aproximarse a la realización y lectura de las escrituras del yo: es posible un pacto novelesco, en el que haya identidad nominal, autor, narrador, personaje, pero la identidad no es referencial.

En El pacto autobiográfico (bis), Lejeune advierte que esta incursión de Doubrovsky en su propuesta multiplicó sus interrogantes, lo que lo condujo a continuar con sus investigaciones. La aproximación de la novela autobiográfica a la autobiografía, anota Lejeune, "ha hecho más confusa que nunca la frontera entre los dos campos. Esta indecisión es un estímulo para la reflexión teórica: ¿en qué condiciones el nombre propio del autor puede ser considerado por el lector como 'ficticio' o ambiguo?" (1994: 135). Ya en estas consideraciones, Lejeune advierte, en la propuesta de Doubrovsky, un indecidible, lo que complicará el escenario teórico.

La autoficción puede, en efecto, resultar un indecidible en relación con las teorías desarrolladas hasta entonces, por una parte, sobre la autobiografía y, por otra, sobre la novela autobiográfica. La identidad entre el autor, el narrador y el personaje, en una obra de "ficción", evidentemente planteaba el resquebrajamiento de las certezas teóricas desarrolladas hasta el momento. Sin embargo, la novela de Doubrovsky, publicada en 1977, no era la primera de su tipo y tampoco inauguraba una forma de desestabilizar a la autobiografía como género. Dos antecedentes habían cuestionado con igual o mayor fuerza los supuestos de Lejeune: Edad de hombre (1939) de Michel Leiris y Roland Barthes por Roland Barthes (1975). Uno de los aspectos relevantes que Lejeune observa en la autobiografía de Leiris es la subsunción de la estructura cronológica a la temática. En Edad de hombre, dice el autor, Leiris realizó el proyecto secreto de toda autobiografía, invertir el orden de la cronología y de la significación. La narración autobiográfica tradicional elige como estructura principal el orden cronológico, sobre todo, la explicación diacrónica causa-efecto, reduciendo el orden temático a una estructura secundaria, subsumida a la otra (Lejeune apud Eakin, 1994: 18). En Roland Barthes por Roland Barthes, Lejeune considera que hay una importante ruptura en relación con la autobiografía, porque constantemente se cuestionan los supuestos teóricos que la sustentan. Hacia el final de El pacto autobiográfico (bis), el teórico francés confiesa su confusión y señala: "Sin duda la autocrítica, al igual que la autobiografía, es una empresa imposible..." (1994: 145). 


\section{El antipacto: Roland Barthes por Roland Barthes}

Roland Barthes por Roland Barthes, escrito entre el 6 de agosto de 1973 y el 3 de septiembre de 1974, está conformado por fotografías y texto escrito. En la primera cuarta parte del libro aparecen treinta y cinco imágenes, algunas son fotografías de la madre y abuelos de Roland Barthes, otras, de él mismo siendo niño, joven, estudiante y profesor. También hay fotografías de sitios en los que vivió o por los que paseó, acompañadas por leyendas. Hay una imagen sobre su firma y una cartilla del hospital. En las siguientes tres cuartas partes, siguiendo un orden alfabético - aunque no de manera absolutahay doscientos veinticinco apartados, que constituyen reflexiones expuestas en fragmentos o aforismos, sobre la escritura, la autobiografía, el sujeto y el autor, entre muchos otros asuntos, y, en algunos párrafos, se describen brevemente experiencias personales. En esta sección hay también unas cuantas imágenes. Ahora bien, aunque es posible, en el plano material, realizar una distinción como la que acabamos de hacer, si nos limitamos a ella podríamos no captar el funcionamiento de las imágenes en relación con el texto. La parte que contiene, en su mayoría, a las fotografías es interdependiente de aquella predominantemente verbal. La relación entre estas partes provoca diseminación del sentido, por lo que resulta imposible llegar a una síntesis que permita comprender una historia de vida, basada en sucesión causal de acciones. Este juego crea un indecidible: un texto, a la vez, autobiográfico y la desconstrucción de la autobiografía. Las imágenes no son ilustraciones, sino incrustaciones en otro soporte, el verbal, que provocan pliegues de sentido en la pretendida historia de vida que se narra de manera abrupta. Es decir, no sólo la organización fragmentaria del texto verbal, sino la incrustación de las imágenes - y de los propios textos que aparecen al pie de las imágenesprovocan desdoblamientos constantes en el texto o derivas del sentido.

En una nota introductoria, redactada una vez concluido el libro, Barthes explica por qué incorporó las fotografías y qué relación tienen con la escritura. Al inicio se lee: "Para comenzar, he aquí algunas imágenes: ellas son la porción de placer que el autor se otorga a sí mismo al terminar su libro" (1978: 5). Esta advertencia al lector es interesante, ya que en ella Barthes justifica la inclusión de fotografías de diversas etapas de su vida y no sólo las de infancia. De acuerdo con las reflexiones expuestas en $E l$ placer del texto (1973), el autor se da a sí mismo la ocasión de experimentar placer, algo así como "el gusto fantasmático de la 'realidad' (1989: 86)", lo que se contrapone al goce, que consiste en "un placer en pedazos" (1989: 83). La inserción de fotografías de infancia parece provocar goce, mientras que las de la edad adulta funcionarían en el ámbito del placer. Vayamos por partes. La inserción de las imágenes de infancia se explica, aparentemente, a partir de la teoría lacaniana de "El estadio del espejo". Aunque no puede afirmarse que Barthes haya basado su reflexión totalmente en la teoría de Jacques Lacan, tampoco puede negarse que haya una relación. El destacado comentarista de la obra de Barthes, Steven Ungar, ha señalado que aun cuando el autor sugiera que no utilizó la teoría de Lacan hasta Fragmentos de un discurso amoroso 
(1977), ya en $S / Z$, publicado en 1970, e incluso en escritos provenientes de finales de los años sesenta, se advierten rasgos de la teoría del psicoanalista (Ungar apud Jay, 1994: 445).Como sabemos, Lacan sostiene que el infans se mira al espejo y reconoce su imagen en otro, lo que le provoca júbilo (Lacan, 1990: 87). Barthes hace explícito en esta nota que son sólo las fotografías de infancia las que le fascinan y provocan goce:

Es un placer de fascinación (y por ello mismo bastante egoísta) [...]. Ahora bien, tengo que reconocer que son sólo las imágenes de mi infancia las que me fascinan (6). [...] Cuando la meditación (el estupor) constituye la imagen como ente separado, cuando hace de ella el objeto de un goce inmediato, ya nada tiene que ver con la reflexión, aun soñadora, de una identidad (1978: 6).

La imaginería, dada por las fotografías de infancia, pone al autor en relación con "eso", otro, de su cuerpo, que no le pertenece, pero tampoco a nadie más:

Al abarcar todo el campo parental, la imaginería actúa como en medium y me pone en relación con el "eso" de mi cuerpo; suscita en mí una suerte de sueño obtuso cuyas unidades son dientes, cabellos, una nariz, una flacura, piernas con largos calcetines, que no me pertenecen, pero que tampoco pertenecen a nadie que no sea yo: heme aquí entonces en un estado de inquietante familiaridad: veo la fisura del Sujeto (precisamente aquello sobre lo que nada puede decir). De esto se desprende que la fotografía de la infancia es, a la vez, muy indiscreta (es mi cuerpo en reverso lo que ella me revela) y muy discreta (no es de "mí" de quien habla).

Por ello, sólo se encontrarán aquí, mezcladas con la novela familiar, las figuraciones de una prehistoria del cuerpo, de este cuerpo que se encamina hacia el trabajo, hacia el goce de la escritura. Pues éste es el sentido teórico de esta limitación: manifestar que el tiempo del relato (de la imaginería) termina con la infancia del sujeto: no hay biografía más que de la vida improductiva. En cuanto produzco, en cuanto escribo, es el Texto mismo el que me desposesiona (afortunadamente) de mi duración narrativa (Barthes, 1978: 6).

Así, ese primer momento de la vida, la infancia, no puede mostrarse como no ocurrió, es decir con escritura, por lo que Barthes acude a las imágenes, mientras que la vida productiva, como la llama, no puede no mostrarse como escritura.

La inclusión de imágenes de juventud y edad adulta, así como de sitios visitados o la cartilla del hospital, no se explican con la teoría lacaniana de "El estadio del espejo", lo que indica que Barthes no se adhirió totalmente a esta dimensión de la teoría del psicoanalista. Al parecer, en Roland Barthes por Roland Barthes, el autor anticipaba algunas intuiciones sobre la fotografía, que desarrolló plenamente en el que fue su último libro, La cámara lúcida (1980), en relación con la idea de que lo que se oculta detrás de la fotografía es la muerte, ya que con la fotografía desaparece el referente, muere el sujeto fotografiado. Así, la fotografía no muestra lo que ya no es, sino lo que ha sido: "Ante una foto, la conciencia no toma necesariamente la vía nostálgica del 
recuerdo [...], sino, para toda foto existente en el mundo, la vía de la certidumbre: la esencia de la fotografía consiste en ratificar lo que ella misma representa" (Barthes, 2014: 98). Es importante señalar que detrás de la portada del libro Roland Barthes por Roland Barthes aparece una imagen más, una especie de negativo fotográfico, en el que se lee: "Todo esto debe ser considerado como si fuese dicho por un personaje de novela" (1975). Se trata de una fotografía con un texto que, desde el punto de vista semiótico, puede decirse que funciona en relación con ambos soportes, el visual y el verbal: es negativo fotográfico y es texto. Si esto es así, entonces el conjunto de fotografías también es de un personaje de ficción.

Barthes señala que el umbral de la vida productiva, es decir, el correspondiente propiamente a la escritura ocurre a partir de su salida del sanatorio, cuando tenía aproximadamente veinte años:

El imaginario hecho de imágenes se detendrá entonces en el umbral de la vida productiva (que para mí fue la salida del sanatorio) y [entonces] aparecerá un imaginario distinto: el de la escritura. Y para que este imaginario pueda desplegarse (y que tal es la intención de este libro) sin ser nunca retenido, asegurado o justificado por la representación de un individuo civil, para que sea libre respecto a sus signos propios, nunca figurativos, el texto seguirá adelante sin imágenes, a no ser por las de la mano que va trazando (Barthes, 1978: 6).

En este imaginario, el de la escritura, el propiamente simbólico, Barthes desconstruye la totalidad de los presupuestos de la autobiografía tradicional, desde el punto de vista formal. No se expone la narración cronológica de la vida del escritor y el relato no comienza por la infancia; tampoco hay cronología de hechos; lo que encontramos es un conjunto de fragmentos, separados por una palabra o sintagma, a manera de entrada de un diccionario. Esta escritura fragmentaria es aquella de quien busca el goce - y no el placer- a partir del resquebrajamiento del lenguaje, de su desfiguración. En la escritura fragmentaria no tiene cabida un sujeto que se construye a partir de la red del lenguaje, sino, más bien, la muerte de este sujeto. El lenguaje y las imágenes de adulto son configuraciones en las que muere el sujeto.

En el primer fragmento, Barthes advierte que el escrito es activo/reactivo:

Activo/reactivo. En lo que escribe hay dos textos. El texto I es reactivo, movido por indignaciones, temores, réplicas interiores, pequeñas paranoias, defensas, escenas. El texto II es activo, movido por el placer. Pero al irse escribiendo, corrigiendo, al irse plegando a la ficción del Estilo, el texto I se hace a su vez activo; entonces pierde su piel reactiva, que sólo subsiste por placas (en pequeños paréntesis) (Barthes, 1978: 47).

$\mathrm{Al}$ escribir desde la subjetividad, el texto es reactivo, pero pronto se convierte en activo, porque es sólo estilo, escritura. No hay sujeto, ni autor, ni obra, sino escritura, texto o estilo. Así, no puede afirmarse que alguien es autor de una obra, porque sólo 
hay texto. Desde este momento, se establece la imposibilidad de la autobiografía en el sentido tradicional.

Como se observa en el fragmento anterior, se ha utilizado la tercera persona, cuando dice: "en lo que escribe", es decir, en lo que (él) escribe, lo cual resquebraja la unidad de la posible voz autoral, lo que provoca ambigüedad. No se trata de una estratagema simple, no es una autobiografía en tercera persona y un juego de iniciales: RB, es un texto: "Escribo un texto y lo llamo RB": el resto es el texto, que es RB. El uso de la tercera persona y de las iniciales RB, así como el de la segunda persona que también aparece ocasionalmente, tiene como objetivo, no el desdoblamiento positivo del sujeto, sino su desfiguración. En algunos fragmentos aparece también la primera persona, de manera intercalada. El siguiente es especialmente interesante, ya que no sólo se habla, en primera persona, del uso de la tercera persona y las iniciales, sino también del resultado de escribir sobre lo escrito:

Cuando finjo escribir sobre lo que he escrito antes se produce de igual modo un movimiento de abolición, no de verdad. No busco poner mi expresión actual al servicio de mi verdad anterior (en el régimen clásico, se hubiese sacralizado este esfuerzo bajo el nombre de autenticidad), renuncio a la persecución agotadora de un viejo trozo de mí mismo, no busco restaurarme (como se dice de un monumento). No digo, "voy a describirme", sino: 'Escribo un texto y lo llamo RB". Prescindo de la imitación (de la descripción) y me confío a la nominación. ¿Acaso no sé que, en el campo del sujeto, no hay referente? El hecho (biográfico, textual) queda abolido en el significante, porque coincide inmediatamente con él [...] soy y mismo mi propio símbolo, soy la historia que me sucede: en rueda libre dentro del lenguaje, no tengo nada con qué compararme; y en ese movimiento, el pronombre del imaginario, "yo", se descubre impertinente... (Barthes, 1978: 61).

La escritura sobre lo escrito no es más que la recirculación de significantes, por lo que lo dicho no hace referencia a quien lo dijo, no hay un afuera, un yo, un sujeto que pueda considerarse como autor.

Este libro, en el que Barthes toma como pre-texto a la autobiografía, es, a la vez, la presentación de su subjetividad y la desconstrucción de certezas conceptuales que habían apuntalado el género hasta ese momento. Ni desde el punto de vista formal y tampoco en relación con la lectura, este texto se aviene a las consideraciones cuidadosamente realizadas por Philippe Lejeune, de ahí que el propio autor haya considerado Roland Barthes por Roland Barthes como el anti-pacto por excelencia (Lejeune, 1994: 142).

Si este texto desconstruye las certezas conceptuales de la autobiografía, ¿podrá considerarse autoficción? Aun cuando se ha escrito mucho sobre la autoficción, para realizar esta reflexión tomaremos únicamente el desarrollo inicial del término, más próximo a la descripción, que a la conformación teórica de un nuevo género. En la contraportada de su novela Fils, de 1977, Serge Doubrovsky escribió: “"Autobiografía'. No, ése es un privilegio reservado a los importantes de este mundo, en el otoño de su vida y en un estilo bello. Ficción de acontecimientos y de hechos estrictamente reales; 
si se quiere, autoficción, al haber confiado el lenguaje de una aventura a la aventura del lenguaje" (Doubrovsky, 2012: 53). Dicho de otro modo, los hombres comunes, que no están en la "edad madura", no tienen derecho a la escritura de su autobiografía. ¿Cómo se identifica, entonces, un texto como éste? La respuesta de Doubrovsky es: autoficción, término que utiliza más de manera nominal que conceptual. Roland Barthes por Roland Barthes no es, evidentemente, la historia de un hombre maduro que ha adquirido el derecho a escribir su vida, por lo que podríamos decir, en principio, que el libro está más próximo a la autoficción. Podría decirse, asimismo, que el libro está muy cercano a la otra idea importante, incluida en el párrafo de la contraportada: "si se quiere, autoficción, al haber confiado el lenguaje de una aventura a la aventura del lenguaje" (2012: 53); es decir, a la propuesta de una escritura que abandona "el discurso cronológico-lógico en beneficio de una divagación poética, de un verbo sin rumbo fijo, donde las palabras tiene prelación sobre las cosas..." (Doubrovsky, 2012: 53).

Con este planteamiento, Doubrovsky se suma a la idea de que esa escritura del yo es la configuración de una máscara de sí mismo y el resto es ausencia, lo que lo aleja de la autobiografía y le permite explorar las posibilidades de la expresión lingüística, utilizando hechos y datos de su propia vida. No satisfecho con esto, el escritor añadió una complicación más a la novela. En su ensayo "Autobiografía/Verdad/Psicoanálisis", de 1980, afirma que la estructura de Fils es análoga a la experiencia del psicoanálisis, pero a diferencia de aquellas concepciones en las que se acude a la reconstrucción posanalítica, este texto es la sesión misma.

En principio, podría decirse que el libro Roland Barthes por Roland Barthes está mucho más próximo a la autoficción que a la autobiografía: hay identidad nominal, entre autor, narrador y personaje, a través de las siglas del nombre, RB, se trata de ficción de acontecimientos estrictamente reales y "se ha confiado el lenguaje de una aventura a la aventura del lenguaje", como quería Doubrovsky. Incluso podríamos agregar que la tan comentada frase ubicada inmediatamente después de la portada del libro de Barthes, a la que ya nos hemos referido: "Todo esto debe ser considerado como dicho por un personaje de novela" (Barthes, 1978), confirma su carácter autoficcional. Además, este libro no pretende ser un discurso de la sinceridad, como lo fuera la autobiografía en sus orígenes, con las Confesiones de J. J. Rousseau, característica que lo acerca aún más a la autoficción, de acuerdo con el señalamiento de Darrieussecq (2012). Incluso, se ha observado que este libro, de manera semejante a la novela Fils, acude a la teoría psicoanalítica, lo que puede advertirse no sólo con el recurso a la teoría lacaniana de "El estadio del espejo", antes mencionada, sino con la disposición secuencial del libro, que sigue cierta pauta inspirada en el psicoanalista: desde el estadio de lo Imaginario hasta el estadio de lo Simbólico (Jay, 1994: 447).

Sin embargo, consideramos impreciso vincular, de manera absoluta, el libro de Barthes a la descripción hecha por Doubrovsky. En Fils, el autor conserva la identidad nominal entre el autor, el narrador y el personaje y, además, refiere anécdotas de su propia vida, narradas en primera persona: "Como en la autobiografía escrupulosa, todas las andanzas del relato están literalmente sacadas de mi propia vida; los lugares, las 
fechas han sido maniáticamente verificados. La parte de invención novelesca se reduce a proporcionar el marco y las circunstancias de una pseudojornada, que sirve de cajón de sastre a la memoria" (Doubrovsky, 2012: 53). En Fils, las anécdotas están tomadas de la vida y, con la "aventura del lenguaje", el sujeto construye rigurosamente una ficción que, a la vez, es lo real. Doubrovsky dice al respecto: "Si la verdad de un sujeto es la ficción que rigurosamente se construye, la verdad de una ficción es ficticia. Más aún, lo ficticio, para un sujeto, es el orden mismo de lo real" (Doubrovsky, 2012: 63). La autoficción es la ficción que el escritor ha decidido darse a sí mismo, su autofiguración, autocrítica, autoanálisis. Así, la autoficción empuja a la indeterminación y la ambigüedad hasta los límites por medio de la suplantación.

Manuel Alberca, quien ha propuesto que el pacto de lectura de la autoficción es ambiguo, ha escrito al respecto:

El yo autoficticio es un yo real e irreal, un yo rechazado y un yo deseado, un yo autobiográfico e imaginario. [...] No renuncia a nada pues está abierto a toda clase de metamorfosis personales y de suplantaciones fantásticas, que le convierten en otro sin dejar de ser él mismo, es decir, sin dejar de saber que yo es y no es otro (Alberca, 2007: 207-208).

De acuerdo con el análisis que Genette hace en Umbrales (2001), podría decirse, quizá, que Fils, de Doubrovsky, es una autobiografía camuflada con el paratexto "novela", que aparece en la portada. Aunque así fuera, esto no demerita la respuesta que provoca en los lectores. Este sujeto que descubre o borra nuevas pistas y complica la imagen de sí mismo es, para el lector, el autor, narrador, personaje, que expresa ficcionalmente una verdad. Ni sincero ni hipócrita, sino reconstructor que ofrece sus múltiples repliegues al lector, quien capta, en relación con la pluralidad, la voluntad de congregar, lo cual configura ya un sentido.

En relación con Roland Barthes por Roland Barthes, Genette escribió que en el cliché autógrafo de la contracubierta, "Todo esto debe ser leído como personaje de una novela de ficción", se advierte un acto ilocutivo de autoridad e incluso de autoritarismo (Genette, 2001: 179), que, agregamos, puede incluso producir lo contrario de lo que pretende; es decir, que el lector lea como si se tratara no de la expresión del diferimiento, sino de la positividad de una vida, que no es lo mismo que la verdad de una ficción.

La autoficción resulta ser un indecidible entre la autobiografía y la novela del yo, porque la identidad nominal entre el autor, el narrador y el personaje harán dudar constantemente al lector, no en relación con los constitutivos teóricos del género, no sobre la cualidad de verdad o de la sinceridad. Esta identidad nominal provocará indeterminación en una dimensión propiamente existencial en el lector. Roland Barthes por Roland Barthes es también un indecidible que, sobre todo, plantea retos a cualquier intento de fijación conceptual genérica. Es un texto que sorprende por la capacidad de diseminación del sentido, por su constante juego deconstruccionista, por 
su importante aporte al pensamiento crítico. Nos parece que, en este caso, puede hablarse de diversos pactos de lectura.

\section{Consideraciones conclusivas}

A pesar de los cuestionamientos provocados por Roland Barthes por Roland Barthes, Lejeune insiste en que este texto acaba por ser lo que niega: "parece ser el anti-Pacto por excelencia y propone un juego enloquecedor de lucidez sobre los presupuestos del discurso autobiográfico - tan vertiginoso que acaba por hacer creer al lector que no hace lo que en realidad hace" (1994: 142). De acuerdo con Lejeune, este libro de Roland Barthes desestabiliza la mayoría de los supuestos teóricos sobre la autobiografía desarrollados hasta entonces, pero, al final, hace lo que niega, es decir, acaba por existir: "por muy imposible que resulte la autobiografía, ello no le impide en absoluto existir. Quizá, al describirla, yo haya tomado [...] mi deseo por la realidad: pero lo que he querido hacer, es describir ese deseo en su realidad, que consiste en ser compartido por un gran número de autores y de lectores" (1994: 142).

Coincidimos con Lejeune en que Roland Barthes por Roland Barthes acaba por hacer lo que niega. Sin embargo, esto no implica que ese libro sea una autobiografía, ni desde el punto de vista formal ni en relación con la lectura. Hemos señalado en la introducción que ya en el título del libro podemos observar un interesante juego de lenguaje que crea un indecidible. El lector puede asumir que, en apariencia, en este libro el autor escribe sobre sí mismo; sin embargo, una mirada más atenta nos permitirá advertir que la partícula "por" (par, en francés) funciona como gozne en el sintagma, provocando que se difiera (différance, en términos de Derrida) el sentido. Aparentemente, un Roland Barthes que funciona como agente en el sintagma proposicional es autor de un Roland Barthes que es paciente, pero la identidad nominal absoluta entre el agente "y el paciente": "Roland Barthes/Roland Barthes" puede llevarnos a concluir que Roland Barthes es agente/paciente o autor/escritura, lo que tendería a desconstruir la relación adposición-posposición en la frase proposicional. El mismo Roland Barthes sostiene que no hay un Roland Barthes referencial, sino sólo textual. Es decir, el autor muere y lo que hay es sólo texto.

Sea como fuere, no puede negarse que Roland Barhtes por Roland Barthes habla de alguien, de un autor al que hoy recordamos, al que no hay que olvidar, del que hay que aprender su capacidad para levantar la piel de las certezas más solidificadas, hasta sangrarlas. Si, en efecto, esta escritura es el texto que es RB, y los lectores sabemos que esa textualidad es voluntad y deseo, pensamiento y sentimiento no de un "yo" entendido como persona real, pero sí de alguien, de un quién, que tuvo la intención de mostrar a alguien: Roland Barthes por Roland Barthes.

En los tiempos que corren es preciso no olvidar a Roland Barthes, entre otros autores de lucidez enorme, para seguir mirando con lentes que resquebrajen la com- 
prensión a partir de perniciosas dicotomías, para tener más elementos de análisis e interpretación y para actuar, en la medida de lo posible, por la paz con justicia.

\section{Obras citadas}

Adorno, Theodor W. 2006. Minima moralia. Reflexiones desde la vida dañada. Obra completa 4. Trad. Joaquín Chamorro MielKe. Madrid: Akal.

AlBerCA, Manuel. 2007. El pacto ambiguo. De la novela autobiográfica a la autoficción. Madrid: Biblioteca Nueva.

BARTHES, Roland. 2014. La cámara lúcida. Trad. Joaquim SALA-SANAHUjA. Barcelona: Paidós.

1996. Crítica y verdad. Trad. José BIANCO. México: Siglo XXI.

1989. El placer del texto y lección inaugural. Trad. Nicolás RosA. México: Siglo XXI.

1984. El susurro del lenguaje. Más allá de la palabra y la escritura. Trad.

C. Fernández Medrano, Buenos Aires: Paidós.

1978. Roland Barthes por Roland Barthes. Trad. Julieta SuCRE. Barcelona: Paidós.

Baudelaire, Charles. 2014. El pintor de la vida moderna. Trad. Martin ScHIFINO.

México: Taurus.

DARRIEUSSECQ, Marie. 2012. “La autoficción, un género poco serio”. Trad. Enric

Sullà. Comp. Ana CASAS. La autoficción. Reflexiones teóricas. Madrid: Arco Libros.

DouBROVSKY, Serge. 2012. “Autobiografía, verdad psicoanálisis”. Trad. David RoAs. Comp. Ana CASAS. La autoficción. Reflexiones teóricas. Madrid: Arco Libros. 1977. Fils. París: Galilée.

EAKIN, John. 1994. "Introducción”. El pacto autobiográfico y otros estudios. Trad. Ana TORRENT. Madrid: Megazul-Endymion.

Genette, Gérard. 2001. Umbrales. Trad. Susana LAGE. México: Siglo XXI.

JAY, Martin. 1994. Downcast Eyes. The denigration of vision in twentieth-century French Thought. Berkeley: University of California Press.

LACAN, Jacques. 1990. "El estadio del espejo como formador de la función del yo [je] tal como se nos revela en la experiencia psicoanalítica”. Escritos I. Trad. Tomás SEgovia. México: Siglo XXI.

LEJEUnE, Philippe. 1994. El pacto autobiográfico y otros estudios. Trad. Ana

TORRENT. Madrid: Megazul-Endymion. 1971. L'autobiographie en France. París: Armand Colin. 